\title{
VALUE INFLUENCING MECHANISM OF GREEN CERTIFICATES IN THE DISCOUNTED CASH FLOW VALUATION
}

\author{
Jussi VIMPARI a, Seppo JUNNILA ${ }^{\text {a,* }}$ \\ a Aalto University, School of Engineering, Real Estate Business, P.O. Box 15800, 00076 Aalto, Finland
}

Received 16 December 2012; accepted 13 May 2013

\begin{abstract}
The market value of green properties is already acknowledged in scientific literature, but it has still remained unclear how green certificates are incorporated into property valuation. In this study, value influencing mechanism of green certificates in property investment is studied. A widely used discounted cash flow (DCF) model for property valuation was constructed and communicated with spreadsheet to industry professionals for valuing an office property in metropolitan Finland. The goal was to understand the value influencing mechanism and even deeper to identify the differences in DCF parameters between certified properties and non-certified properties. The results show that a green certificate increases on average the property value with $9.0 \%$ in the DCF valuation model. Improved yield and net rental income were the main reasons for the higher property value. Interestingly, this is the first known study to empirically open the value influencing mechanisms of green properties presented in earlier theoretical studies.
\end{abstract}

KEYWORDS: Green certificate; Discounted Cash Flow (DCF) valuation; Property value

\section{INTRODUCTION}

Sustainability in the real estate and construction sector has received heaps of attention during the past few years. This attention has lead to a wide range of different sustainability measurement systems for companies and actual building properties. The companies are often measured by different schemes, such as UN's Principles for Responsible Investment in Property Investment (UNPRI 2012) or Global Real Estate Sustainability Benchmark (GRESB 2012). The properties are often measured by different green certificates, such as LEED and BREEAM or with energy efficiency schemes, such as ENERGY STAR. These and other more legislative measures have put pressure on different stakeholders to participate in sustainable development. However, at the same time there is a strategic pull to sustainability due to real environmental, social, and economical benefits that can be gained from investments in sustainable solutions.

Growing amounts of research (e.g., Eichholtz et al. 2010; Fuerst, McAllister 2008, 2009a, 2009b; Pivo, Fisher 2009; Reichardt et al. 2012; Chegut et al. 2014) have examined the economical benefits

\footnotetext{
* Corresponding author. E-mail: seppo.junnila@aalto.fi
}

of the green properties and certificates, especially on how they affect cash flow parameters: rents, maintenance costs, vacancy rates, and yields. Most of the earlier researches have been either surveys with different stakeholders in the sector or regression analysis based on large datasets of certified and non-certified properties in the most mature markets with certificates, such as the U.S. and the U.K. Even though many of the research results indicate a positive relationship between certified buildings and the cash flow parameters, it remains unclear what the actual value influencing mechanisms are and how the green certificate should be incorporated into property valuation.

This paper tries to shed light on the value influencing mechanism of green certificates in the discounted cash flow (DCF) valuation. The research was constructed so that a widely used DCF model for property valuation was constructed and communicated with a spreadsheet and sent to different stakeholders (i.e., property valuers, investors, and developers) for valuing an office property in metropolitan Finland. The participants were asked to valuate the office property first without a certificate and then with a premium level (LEED Platinum) certificate. In addition, both valuation cases 
were asked to be valued with minimum, normal, and maximum scenarios to understand sensitivity and range of valuation possibilities for different DCF input parameters. A total of eight independent responses with 1-3 participants each (two valuers, three investors, and three developers) were received from industry professionals.

The results show that a green certificate increases on average the property value with $9.0 \%$ in the DCF valuation model. All of the respondents valued certified properties higher than noncertified properties. The adjustments by the participants to the DCF input parameters varied significantly with the exception of the estimated yield that was systematically estimated to improve, or in one case to remain the same. In addition to the improved yield, all of the participants improved the net rental income (i.e., rent minus maintenance costs) for certified properties. Interestingly, this seems to be the first empirical study that was able to open the value influencing mechanisms of green properties presented in the earlier theoretical studies.

The research is organized as follows. The next section reviews relevant earlier research on the economical relationship between green certificates and property value. Also, the DCF approach for property valuation is explained and discussed with the context of green certificates. In the end of the section a research hypothesis is formulated. In the section after that, the research methodology is presented and results analysed. Finally, conclusions of the study are discussed.

\section{GREEN CERTIFICATES AND PROPERTY VALUATION}

Growing amounts of research (e.g., Eichholtz et al. 2010; Fuerst, McAllister 2008, 2009a, 2009b; Pivo, Fisher 2009; Reichardt et al. 2012; Chegut et al. 2014) have examined the economical benefits of the green certificates and energy efficiency schemes. Falkenbach et al. (2010) conducted a study for identifying drivers and benefits of sustainable buildings for property investor. Falkenbach et al.'s (2010) framework of drivers for property investor is presented in Figure 1.

Similar categorizations of the drivers presented in Figure 1 have been identified in other studies as well. For example, Sayce et al. (2007) divided the drivers into two main categories: legislation and policies as top-down drivers, and market-led drivers as bottom-up drivers. The framework presents environmental and energy certificates, i.e., green certificates as one of the drivers for property investor. The green certificates have gained popularity, especially construction companies and consultants are fast adopting them to use. Gradually, also property investors have started to become more interested in these certificates, even though the costs and benefits between investors and tenants are not yet clear with well acknowledged split incentive and principal-agent problems (Falkenbach et al. 2010; Golubchikov 2009). In the framework of Falkenbach et al. (2010), the costs and benefits are presented as property level drivers, i.e., the actual components that form cash flows of properties

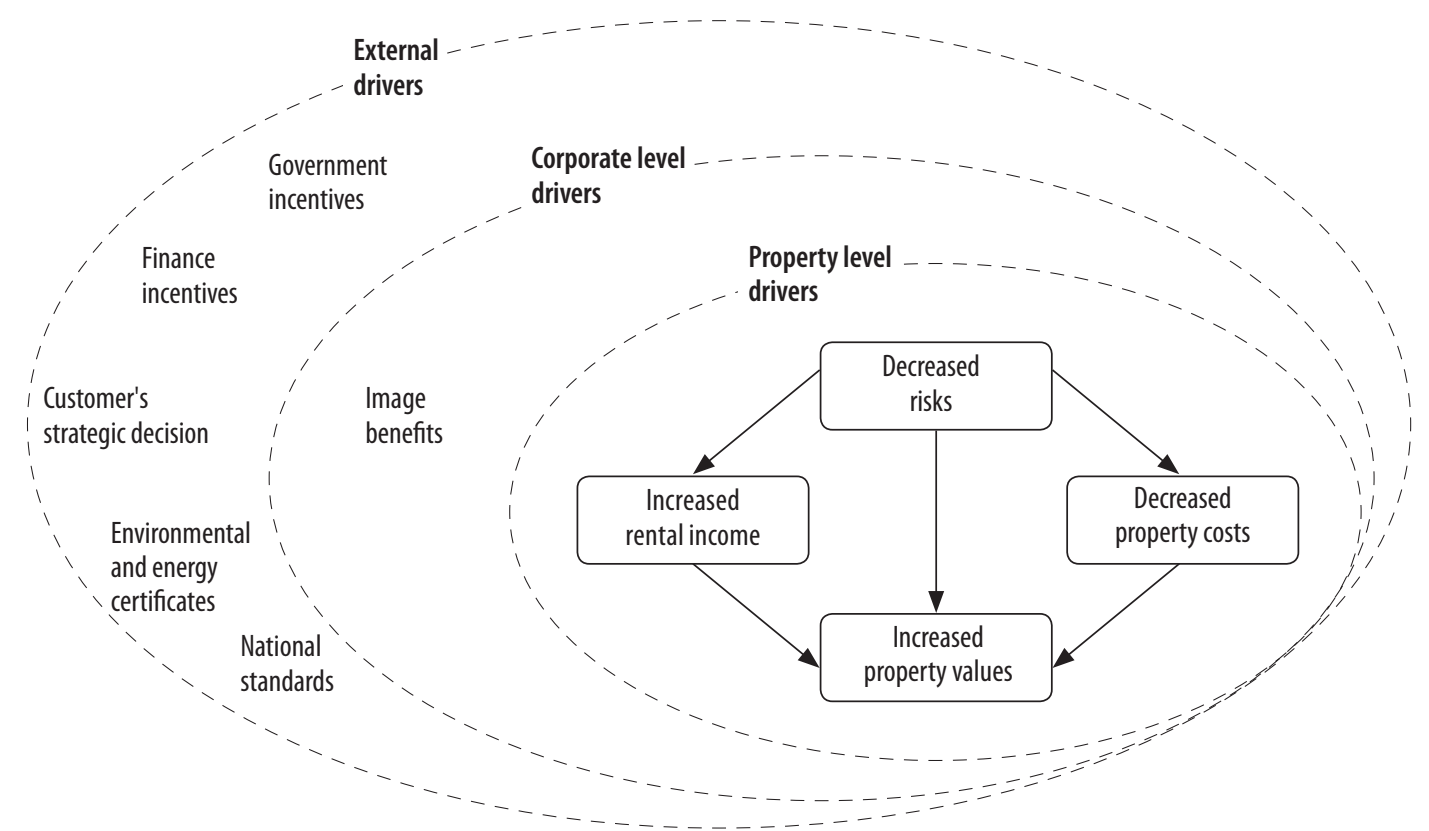

Fig. 1. Framework of drivers for property investor (Falkenbach et al. 2010) 
and eventually property values. In the following, previous research on the economic impact of green certificates on property level drivers is presented.

The increased rental income has been studied a lot. Several large global real estate consultant companies have carried out surveys to study whether tenants are willing to pay more for certified buildings. Colliers (2007), Jones Lang LaSalle (2008), and Cushman and Wakefield (2009) found that $63.0 \%, 70.0 \%$, and $39.0 \%$ of the respondents are willing to pay a rent premium, respectively. Sayce et al. (2007) carried out three surveys in 1995, 2000, and 2005 to institutional investors, property valuers, developers, and banks; approximately $80.0 \%$ in 1995 and approximately $70.0 \%$ in 2000 and 2005 of the respondents expected that sustainability would affect rental prices within the next five years. Fuerst and McAllister (2008, 2009a) conducted hedonic regression analysis on U.S. commercial real estate data to compare rents between LEED or ENERGY STAR certified buildings and non-certified buildings; they found that there is a $4.0-5.0 \%$ rent premium for certified buildings, in 2009 their update found a premium of 6.0\%. Eichholtz et al. (2010) also carried out a regression analysis and found that ENERGY STAR certified buildings carry a $2.8 \%$ rental premium whereas LEED certified buildings have no premium. Wiley et al. (2010) conducted a regression analysis and found that ENERGY STAR and LEED certified buildings have a rental premium of $7.3-8.9 \%$ and $15.2-17.3 \%$, respectively. Pivo and Fisher (2009) analysed net operating income with regression analysis and found that ENERGY STAR properties have a rental premium of $4.8 \%$ to non-certified buildings. Reichardt et al. (2012) ran regression models over a very large dataset over 2000-2010 period and found that both ENERGY STAR and LEED certified buildings had rental premiums over the whole period, averaging $2.5 \%$ for ENERGY STAR and 2.9\% for LEED. Chegut et al. (2014) ran also regression models over a large U.K. dataset to found that BREEAM certified buildings have a rental premium over non-certified buildings, the range of the premium depending on the building qualities.

The decreased property costs have also been studied (it should be noted that the decreased property costs are considered as decreased operating expenses, not decreased construction costs). Shiers (1999) found that BREEAM-certified buildings have $6.0-30.0 \%$ lower energy costs than noncertified buildings. However, the sample size was very small, 14 buildings, thus, the author could not control for building specifications. Miller et al. (2008) found from that office buildings with ENERGY STAR certification have $30.0 \%$ lower energy costs than non-certified buildings. In this case the sample size was 643 certified and 2000 non-certified class A office buildings built in 1970 with an area of at least 18000 square meters and height of five stories or more. Turner and Frankel (2008) found from a sample of 121 properties that LEEDcertified properties have 25.0-30.0\% lower energy usage than properties on average. Pivo and Fisher (2009) found that ENERGY STAR certified buildings have $9.8 \%$ lower utility expenses than noncertified buildings.

Falkenbach et al. (2010) summarised that "the decreased risk in sustainable buildings typically builds on either the lower risk of future obsolescence or lower risk of vacancy", i.e., if sustainable buildings becomes mainstream then non-sustainable buildings have more problems with obsolescence and vacancy rates. Fuerst and McAllister (2009b) found from a regression analysis that LEED and ENERGY STAR certified properties have $8.0 \%$ and $3.0 \%$ higher occupancy rates, respectively. Miller et al. (2008) found 2.0-4.0\% higher occupancy rate for ENERGY STAR properties. Wiley et al. (2010) found that difference in vacancy rates between $\mathrm{EN}$ ERGY STAR and LEED properties to non-certified buildings are $10.2-11.0 \%$ and $16.2-17.9 \%$, respectively. Pivo and Fisher (2009) found that ENERGY STAR certified building have $0.9 \%$ lower vacancy rate than non-certified buildings. Reichardt et al. (2012) found that ENERGY STAR labelled buildings have $4.5 \%$ higher occupancy rates. Chegut et al. (2014) found that the average lease length in BREEAM certified properties is longer by almost three years than non-certified buildings.

Last component of the property level drivers is the increased property value. As Figure 1 presents, all the other drivers increased property value. Additionally, supply and demand of sustainable buildings impacts the value too (Falkenbach et al. 2010). Cushman and Wakefield (2009) found from a survey that $44.0 \%$ of landlords are willing to pay a price difference for sustainable properties. Sayce et al. (2007) found in their survey that $23.0 \%$ in $2005(80.0 \%$ in $1995,44.0 \%$ in 2000$)$ of the respondents thought that investment yields are already affected by sustainability, and over $70.0 \%$ thought that it would happen within the next five years. Fuerst and McAllister (2008, 2009a) used a hedonic regression model to analyse whether certified buildings have a price premium. They found that LEED buildings have a $26.0 \%$ (35.0\% in 2009) 
price premium and ENERGY STAR buildings have a $25.0 \%$ (31.0\% in 2009) price premium. Eichholtz et al. (2010) also did regression analysis and found that ENERGY STAR and LEED certified buildings had $16.0 \%$ price premium over non-certified properties. Wiley et al. (2010) found from regression analysis that ENERGY STAR and LEED certified buildings carried a price premium of $320 \$$ per square meter and $1390 \$$ per square meter, respectively. Pivo and Fisher (2009) found that ENERGY STAR certified buildings have 13.5\% higher market values than non-certified buildings. Chegut et al. (2014) found that BREEAM certified buildings have a $26.0 \%$ transaction premium over non-certified buildings. McGareth (2012) ran regression models on U.S. commercial office property data and found that eco-certified properties have $0.36 \%$ - unit improved capitalization rate (i.e., yield) than non-certified properties.

Increased construction costs of green buildings should also be considered. Kats (2003) conducted a study with interviews to building representatives and architects in order to find out whether LEED certified buildings have higher construction costs than conventional buildings in the U.S. It was found out that on average the construction cost premium for green buildings are slightly less than $2.0 \%$; with LEED Platinum the premium was $6.5 \%$, but this was based on only one building. Matthiessen and Morris (2004) studied the cost difference between green buildings and buildings without a sustainable goal in different locations (climates) in the U.S., and found out that the premiums were, depending on the climate, $7.6-10.3 \%$ for LEED Platinum, 2.7-6.3\% for LEED Gold, and $1.0-3.7 \%$ for LEED Silver. The study was updated in 2006, and it was found out that LEED-projects can be achieved within same budgets than nonLEED projects, and that the variations between building costs are very large, i.e., there are low and high cost green buildings and low and high cost non-green buildings (Matthiessen, Morris 2007). Even though construction costs are not directly part of the DCF valuation, it might be important for the valuer to understand how do they differ from traditional designs.

To conclude, it was found that most of the researches indicate that certified properties are more valuable than non-certified properties. The data in the above-mentioned researches have been mainly from U.S., which is the most mature property market for certified properties but at the same time very different compared to other markets. For example, the basic construction quality in the
Nordics might differ heavily from the basic construction quality in the U.S. For example, several developers have claimed that the even the LEED Gold level can be reached in Finland with business-as-usual designs. Furthermore, most of the research is done with hedonic regression models, of which many have tried to account for property-specific characteristics with as best as possible. These models have been developed and become better as more data becomes available since more properties are certified. Yet in practice different stakeholders are sceptical what is the true mechanism of value influence with certificate, i.e., is it the "brand" value of the certificate or is it the overall better technical solutions and construction quality which happens to decrease the operating expenses and thus, having a positive impact on the property price, or is it a combination of these where operating expenses are decreased but at the same time yield and vacancy are decreased as well because of the brand value of the certificate.

The traditional methods for property valuation are the cost approach (i.e., property value is based on construction costs), the sales comparison approach (i.e., property value is based on comparable transactions), and the DCF approach (i.e., property value is based on the present value of future cashflows) (e.g., Lusht 1997). In commercial property investment, the DCF approach is by far the most widely used method since the cost approach does not provide realistic market values, and the sales comparison approach is impractical in use since truly comparable transactions on commercial properties are hard to find. However, often the results produced by the DCF are supplemented with results from the sales comparison method, if possible. Additionally, the cost approach might be used to supplement the results, i.e., comparing potential replacement costs to the property value produced by the DCF. It is further emphasized that the DCF method has been criticized for the possibility of subjectivity in selecting values for input parameters and accordingly DCF results can be inconsistent with empirical market behaviour. Therefore, it is suggested that the validity of the DCF results should always be benchmarked against the other traditional valuation methods when possible.

In the traditional 10-year DCF approach, property value is formed of two components: the present value of net operating income (NOI) from the next 10 years and the present value of exit value that is calculated from 11 th year NOI (i.e., 11th year represents cash flow of the exit year). The NOI is calculated by subtracting vacancy losses 
and operating expenses from potential gross rental income. The exit value is calculated by dividing the 11th NOI with yield, i.e., yield $=$ risk free rate + risk premium + depreciation - growth (inflation); it should be noted that it is common in the Finnish property market (e.g., in contrary to the U.S. market) that yield $=$ discount rate - inflation, i.e., discount rate $=$ yield + inflation, this is done because the inflation and yield have separate effects in the cash flows (e.g., rental and maintenance costs growth are adjusted with inflation, and exit value is calculated using the yield) but used together for discounting (KTI 2013). Finally, it is emphasized that since yield measures risk, the lower the yield, the higher the property value. In this paper, the above-mentioned definition of yield is used.

In practice, the property valuation process with the DCF approach has four key input parameters: rent (€/sqm/month), operating expenses (€/sqm/ month), vacancy (\%), and yield (\%). The operating expenses are often divided into two components: maintenance costs $(€ / \mathrm{sqm} / \mathrm{month})$, and repair and replacement costs ( $€ / \mathrm{sqm} / \mathrm{month})$. In addition, the parameters are usually altered with sensitivity analysis (e.g., $\pm 10.0 \%$ ) to see a range of the potential value. Finally, in theory, the results from the DCF should be equal to the results from direct capitalization (i.e., first year NOI divided by yield) - however, this is fulfilled only if the first year NOI has the same assumptions that are used in the 10-year DCF. In practice, the direct capitalization method is an easy and quick way of getting an approximation of the property value, but the DCF is be used for more accurate property values.

In practice, the parameters for the DCF valuation are drawn from three sources: current lease agreements, available information on the property, and market information. The current lease agreements are straightforward to use and there often is no informational uncertainty associated, except for occasional insolvencies with tenants. The informational uncertainty comes from the two latter sources and it has been noted both in practice and in academics (e.g., French, Gabrielli 2004) that the DCF approach has some serious limitations concerning uncertainty of input information. The uncertainty in property information is associated with the fact that sometimes not enough property information is available to properly understand matters like how is are layouts dividable in terms of leasable area or how does the technical condition impact operating expenses. The market information represents rents, vacancy rates, and yields. All of these three parameters have uncertainty in them since data might not be available for all locations. The uncertainty with rents and vacancy rates can be reduced by hard work (e.g., contacting rental agents, property owners, public sources, etc.). The most subjective of the parameters is the yield, which should be drawn from market information (i.e., with what yields have comparable properties transacted) that is not often available since no transactions have been done. Therefore, the yield has the highest uncertainty of the market parameters.

The earlier research indicated that these parameters are affected by the green certificates, Table 1 summarizes these findings.

The impact of the parameters in Table 1 indicates that all have a positive effect on the property value. However, it should be considered how does the green certificates affect the uncertainty associated with these parameters. For the property information, a valuer should have the extra information of what are the technical differences between certified and non-certified properties. For the market information, the valuer will have even more limited sources of information since at the moment certified properties are a clear minority. Therefore, one could argue that the extra property

Table 1. Summary of the literature review

\begin{tabular}{|c|c|c|}
\hline Parameter & Impact & Research \\
\hline Rent & Increased & $\begin{array}{l}\text { Colliers (2007), Jones Lang LaSalle (2008), Cushman and Wakefield (2009), } \\
\text { Sayce et al. (2007), Fuerst and McAllister (2008, 2009a), Eichholtz et al. (2010), } \\
\text { Wiley et al. (2010), Pivo and Fisher (2009), Reichardt et al. (2012), and Chegut } \\
\text { et al. (2014) }\end{array}$ \\
\hline Operating expenses & Decreased & $\begin{array}{l}\text { Shiers (1999), Miller et al. (2008), Turner and Frankel (2008), and Pivo and } \\
\text { Fisher (2009) }\end{array}$ \\
\hline Vacancy & Decreased & $\begin{array}{l}\text { Fuerst and McAllister (2009b), Miller et al. (2008), Wiley et al. (2010), Pivo and } \\
\text { Fisher (2009), Reichardt et al. (2012), and Chegut et al. (2014) }\end{array}$ \\
\hline Yield & Decreased & Sayce et al. (2007) and McGareth (2012) \\
\hline Property value & Increased & $\begin{array}{l}\text { Cushman and Wakefield (2009), Fuerst and McAllister (2008, 2009a), Eichholtz } \\
\text { et al. (2010), Wiley et al. (2010), Pivo and Fisher (2009), and Chegut et al. (2014) }\end{array}$ \\
\hline
\end{tabular}


value from certificates is associated with future potential that the certificates hold.

The research question was formulated around the identified research problem: what kind of impact does a green certificate have on the DCF input parameters and property value for different stakeholders in the real estate and construction sector? Based on the reviewed earlier literature, it is hypothesized that the participants will increase rent and decrease operating expenses, vacancy, and yield for a certified property, and that these adjustments result to increased property value.

\section{RESEARCH METHODOLOGY AND RESULTS}

A spreadsheet programme based DCF valuation model was developed for a hypothetical office property in Keilaniemi, Espoo, Finland (see Appendix 1). The office had $5000 \mathrm{sqm}$ of rentable space in five floors and it was constructed 10 years ago with no repairs or replacements done since. The rentable space had $20.0 \%$ vacancy at the date of valuation $(40.0 \%$ of the leases had a length of three years and $40.0 \%$ had a length of five years) and the rentable space was considered to be identical and dividable perfectly to smaller areas, i.e., the participant did not have to think how the space is dividable for renting. The Keilaniemi area in Espoo is a very well known office area in Finland and many of the largest Finnish companies (e.g., Nokia, KONE, Neste Oil, Fortum) have their headquarters there. The area was chosen because of the easiness for finding market information, and it was expected that the participants would know it since they are professionals in the real estate and construction sector.

The DCF valuation model was constructed according to the first author's experience as a valuator at one of the largest property investors in Finland. The DCF model was constructed in line with the traditional 10-year model (see Appendix 2). The changeable input parameters in the model were rent $(€ / \mathrm{sqm} / \mathrm{m})$, yearly vacancy rate $(\%)$, yearly maintenance costs $(€ / \mathrm{sqm} / \mathrm{m})$, yearly repair and replacement costs $(€ / \mathrm{sqm} / \mathrm{m})$, and yield (\%). The inflation / growth was assumed to be $2.0 \%$ for the whole 10 year period, and it could not be altered. Currently, this is a standard assumption in the Finnish property sector; it is based on long-term historical inflation of Europe and on the projections of European Central Bank. For clarification, the yield represented discount rate minus inflation, i.e., discount rate is yield plus inflation. The model was tested and it met the theoretical rule that the market value from a 10-year DCF model should be the same as the market value from a direct capitalization (i.e., current net operating income per yield). After the model was ready, the starting inputs were introduced to the model: current rent $20.00 € / \mathrm{sqm} / \mathrm{m}$, yearly vacancy rate $20.00 \%$, yearly maintenance costs $3.50 € / \mathrm{sqm} / \mathrm{m}$, yearly repair and replacement costs $0.30 € / \mathrm{sqm} / \mathrm{m}$, and yield $7.50 \%$. These were thought to be quite neutral inputs and could be easily drawn from market information such as Catella Property Market Trends or Newsec Property Outlook.

The two cases (A and B) with three scenarios each (Normal named "Most Likely", Minimum "Worst", and Maximum "Best", respectively) were produced for measurement. Three scenarios were created in order to gain understanding whether the potential benefits of a certificate differ in the worst and best cases (e.g., in a best case, the certified buildings clearly stands above others). In Case A, the property did not have a green certificate; in Case B the property had a LEED Platinum certificate, which is the highest LEED rating that a property can get. The LEED certification system was developed by the U.S. Green Building Council (USGBC 2012) in 1999, and it is ranking system that allocates points in seven sustainability categories: sustainable sites, water efficiency, energy and atmosphere, materials and resources, indoor environmental quality, innovation in design, and regional priority. There is four certificates level available: Certified, Silver, Gold, and Platinum. The LEED system has gained wide interest around, and by the time of writing this paper there is approximately 860 million square meters of building space participating in the system worldwide, and also in the local Nordic market there are over 50 LEED certified buildings. The LEED certification system was chosen because it seems to be the most popular certification system in Finland and it was assumed that the participants would know what it is. The Platinum rank was chosen because the authors wanted to make a clear difference between a normal and a certified building. Also, if all of the LEED ranks had been included, the valuation would have become too extensive to be executed in practice. As stated earlier, LEED Gold level can be reached in Finland with business-as-usual designs. In the spreadsheet, the main categories of LEED certification system were provided for the participants as supplementary information (see Appendix 1). Theoretical sampling (Eisenhardt, Graebner 2007) was used for selecting participants 
representing the largest companies in real estate investment, development, and valuation with most being members in the Green Building Council Finland (FIGBC 2012), and rest having knowledge of certificates (i.e., valued or own certified buildings).

After the DCF valuation model was ready, it was tested hands-on with two participants. From these meetings, it was concluded that the model was understandable and easy to use. Additionally, from the meetings could be observed that the participants would like to fill the spreadsheet alone without a researcher presence. This was probably due to concentration and contemplation involved in the valuation process. It was concluded that the valuation spreadsheet is understandable without guidance and it could be sent by e-mail to participants for filling. The same spreadsheet was sent to twelve different professionals working in real estate investment, valuation, and development companies. The target was three responses in each category. This theoretical sampling of cases was considered to be sufficient in shedding light to the research question (Eisenhardt, Graebner 2007).

A total of eight participants (two valuers, three investors, and three developers) responded. All of the respondents confirmed that they knew what a LEED certificate is, and did not need additional information regarding it. The amount of responses was considered to be enough since it would already allow analytical generalization of the results. The statistical generalization was not considered necessary due to the strong literature based hypotheses testing nature of the study. Majority of the respondents wanted to remain anonymous, thus, the responses are presented in with codes of $\mathrm{V}=$ Valuer, I = Investor, and D = Developer. Most of the participants called the first author to ask some filling questions but overall the cases were understood well. Furthermore, at least five of the respondents used two or more people in their organization to discuss the possible impact of the certificate in the DCF parameters. This and other comments suggest that the cases were very interesting for the participants, and that the question of certificates impact on property values is becoming increasingly relevant.

All of the parameters that the participants could adjust were collected into one spreadsheet for analysis. Table 2 presents this information. It should be noted that since Vacancy Rate, Maintenance Costs, and Repair and Replacement Costs could be adjusted yearly on the spreadsheet, but here only the means of these yearly values are presented.
Since the differences between non-certified and certified properties are the most interesting part, Table 3 presents a summary of these differences. Means were calculated for the DCF input parameters and for the property values for each group of participants as well as for all of the participants. In addition, descriptive statistics of Median, Min, and Max are presented for all of the participants.

In the following, each of the parameters are analysed in terms of the differences between noncertified properties and certified properties.

Rent $(€ / \mathrm{sqm} / \mathrm{m})$ was adjusted upward by five out of eight (V2, I2, D1, D2, and D3) of the participants in 12 out of 24 scenarios. The adjustments were either $0.50 € / \mathrm{sqm} / \mathrm{m}$ or $1.00 € / \mathrm{sqm} / \mathrm{m}$ with the expectation where D3 adjusted the rent 3.00 $€ / \mathrm{sqm} / \mathrm{m}$ for the normal scenario and $5.50 € / \mathrm{sqm} / \mathrm{m}$ for the min scenario. The D3 had also some other notable selections, which in part explains these higher rents. These are discussed later. These adjustments raise rent means of the normal and min scenarios above the max scenario. Otherwise mean of the max scenario would be the highest between the scenarios. From these responses it is hard to draw inferences whether the certificate actually raises rents.

Vacancy rate (\%-unit) was adjusted downward by five (V2, I1, I3, D1, and D3) of the eight participants in 13 out of 24 scenarios and upward by D3 in two scenarios. For the downward adjustments, the range was from $0.64 \%$-unit to $4.91 \%$-unit, where V2 made minor adjustments (under one 0.80\%-unit) and others higher adjustments (over $1.80 \%$-unit). D3 adjusted the vacancy rate downward (1.91\%-unit) for the max scenario and upward for the normal (5.91\%-unit) and min (17.27\%unit) scenarios. However, the same participant did the above-mentioned high adjustments in the rent as well. It seems that the participant thought that the certified building would fetch a high rent but in return the building would be hard to rent. If this is the case, the logic seems to be somewhat understandable, however, in practice the property owner would probably lower the rent for a higher occupancy rate, i.e., for higher return. As with the rent, it is hard to draw inferences whether the certificate actually decreases vacancy rate.

Maintenance costs $(€ / \mathrm{sqm} / \mathrm{m})$ were adjusted downward by five (V1, V2, I1, I3, and D1) of the participants in 15 out of 24 scenarios. The adjustment range was from $0.10 € / \mathrm{sqm} / \mathrm{m}$ to $0.50 € /$ $\mathrm{sqm} / \mathrm{m}$. Three (V2, I1, and I3) of the participants adjusted the maintenance costs by the same amount in every scenario. V1 adjusted the mainte- 
Table 2. Aggregated inputs/outputs of DCF parameters from all of the responses

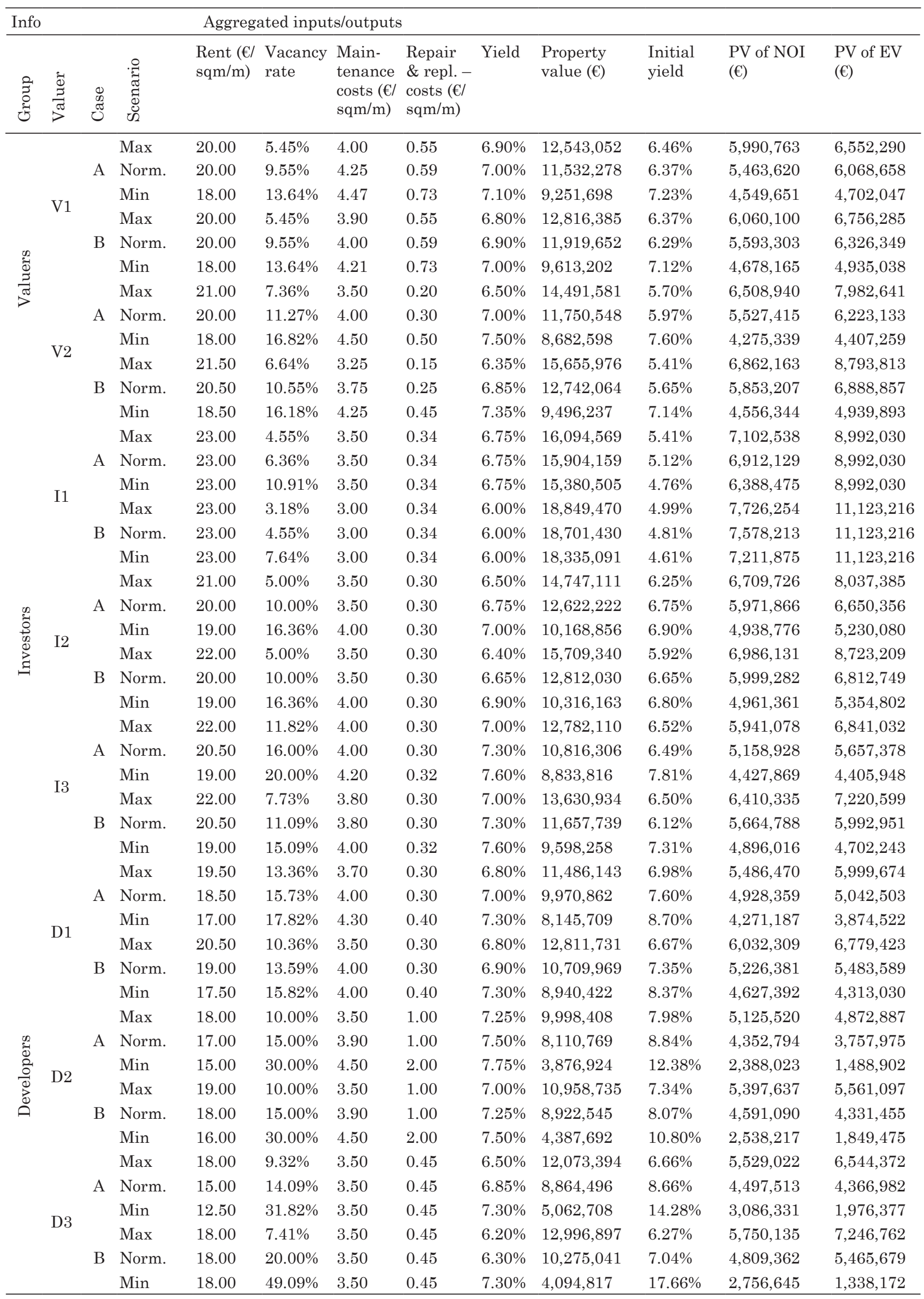


nance costs more in the normal and min scenarios than in the max scenario. D1 adjusted the maintenance costs only for the max and min scenarios. Again, it is hard to draw inferences whether the certificate systematically actually decreases maintenance costs.

Repair and replacement costs $(€ / \mathrm{sqm} / \mathrm{m})$ were adjusted downward $(0.05 € / \mathrm{sqm} / \mathrm{m})$ only by one (V2) of the participants in three out of 24 scenarios. It seems that different stakeholders think that certificates do not have an effect on repair and replacement costs.

Yield (\%-unit) was adjusted downward by seven (all except I3, which had same yields for both cases) of the participants in 18 out of 24 scenarios The adjustment range was from $0.10 \%$-unit to $0.75 \%$-unit. Four (V1, V2, I2, and D1) of the participants made minor adjustments of $0.10 \%$-unit to $0.15 \%$-unit, D2 made a moderate adjustment of $0.25 \%$-unit, D3 moderate to high adjustments of $0.30 \%$-unit to $0.50 \%$-unit, and I1 very high adjustments of $0.75 \%$ unit. From these results, it seems that different stakeholders decreases yield for certified buildings.

Property value (€) was higher in every scenario for all of the participants with an exception for D3 min scenario where the rent-vacancy rate combination caused the property value to be lower for the certified building. Since in 23 out of 24 scenarios certified buildings were valued higher than noncertified, it seems justified to make an analytical deduction that the property value is higher for certified buildings than non-certified. This finding is illustrated in Figure 2 that presents means of the property values with and without certificates for every group and for all of the participants. Examining the normal scenarios in Figure 2 shows that there are property value premiums of $5.9 \%$ (Valuers), 9.0\% (Investors), 11.1\% (Developers), and 9.0\% (All) for certified buildings. The standard deviation of value premium per average property value for the same groups are $3.7 \%, 10.3 \%, 4.1 \%$, and $7.2 \%$, respectively. The standard deviations are high in absolute euros, which indicate that there is not a clear consensus of the size of the positive impact between respondents.

In Table 2 initial yield (i.e., $1^{\text {st }}$ year NOI per Property Value) is also presented as extra information. In practice, the initial yield is an important measure because the investor wants to know what return the investor receives in the beginning of the investment. All 24 of the responses except the D3 min scenario have improved initial yields, ranging from $0.08 \%$-unit to $1.63 \%$-unit. Averaging the initial yields for all of the responses, the initial yield is decreased $0.31 \%$-unit for the max scenario, $0.48 \%$-unit for the normal scenario, and increased $0.02 \%$-unit. For the max and normal scenarios, this could be interpreted as that certified buildings are less risky because less return are required from them.

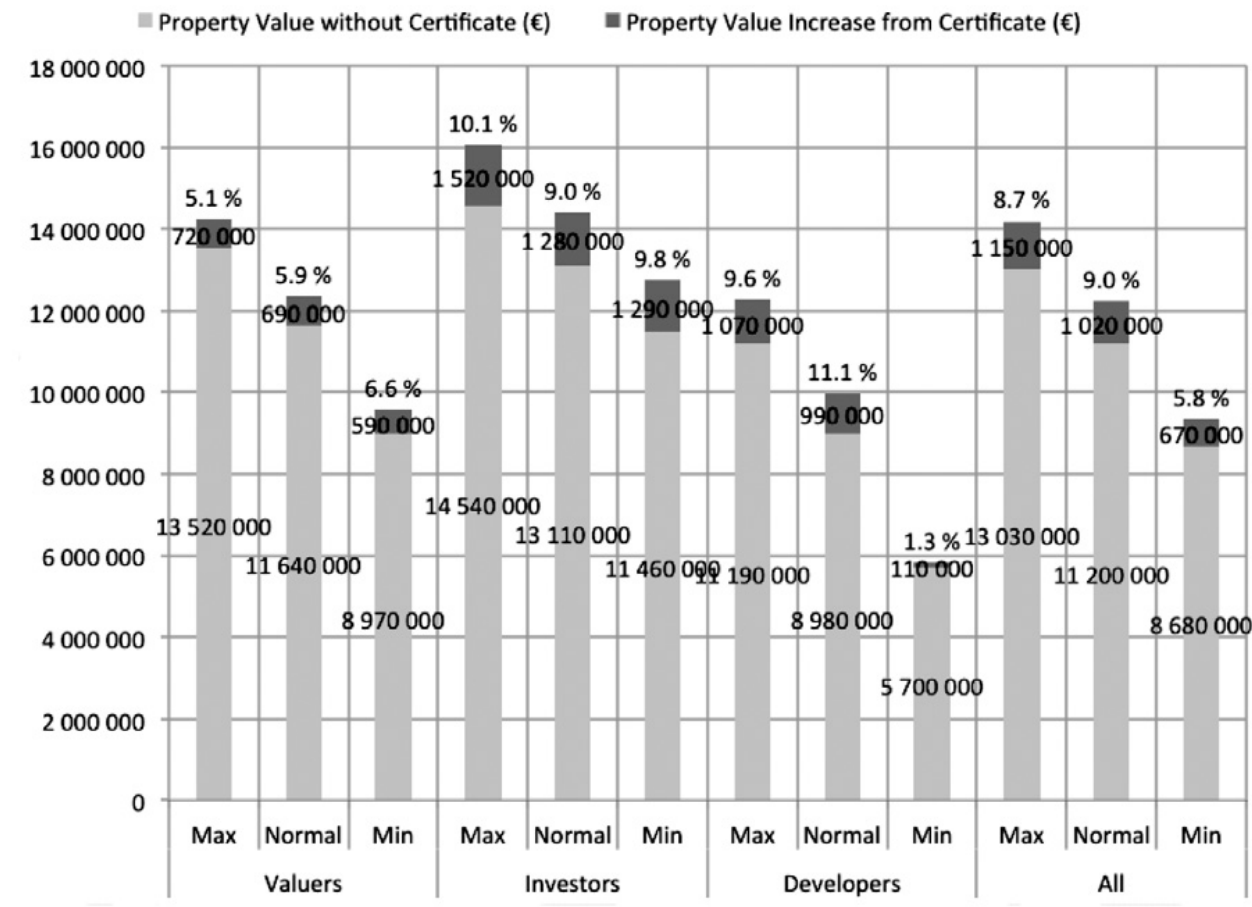

Fig. 2. Property value means with and without certificates 
Table 3. Summary of the differences in the DCF parameters between non-certified and certified properties

\begin{tabular}{lllllllll}
\hline Parameter & Scenario & Valuers & Investors & Developers & All & & \\
\cline { 5 - 8 } & & Mean & Mean & Mean & Mean & Median & Min & Max \\
\hline Rent (€/sqm/m) & Max & 0.25 & 0.33 & 0.67 & 0.44 & 0.25 & 0.00 & 1.00 \\
& Normal & 0.25 & 0.00 & 1.50 & 0.63 & 0.25 & 0.00 & 3.00 \\
& Min & 0.25 & 0.00 & 2.33 & 0.94 & 0.25 & 0.00 & 5.50 \\
Vacancy rate & Max & $-0.36 \%$ & $-1.82 \%$ & $-1.64 \%$ & $-1.39 \%$ & $-1.05 \%$ & $-4.09 \%$ & $0.00 \%$ \\
(\%-unit) & Normal & $-0.36 \%$ & $-2.24 \%$ & $1.26 \%$ & $-0.46 \%$ & $-0.36 \%$ & $-4.91 \%$ & $5.91 \%$ \\
& Min & $-0.32 \%$ & $-2.73 \%$ & $5.09 \%$ & $0.81 \%$ & $-0.32 \%$ & $-4.91 \%$ & $17.27 \%$ \\
Maintenance & Max & -0.18 & -0.23 & -0.07 & -0.16 & -0.15 & -0.50 & 0.00 \\
costs (€/sqm/m) & Normal & -0.25 & -0.23 & 0.00 & -0.15 & -0.10 & -0.50 & 0.00 \\
& Min & -0.26 & -0.23 & -0.10 & -0.19 & -0.23 & -0.50 & 0.00 \\
Repair and & Max & -0.03 & 0.00 & 0.00 & -0.01 & 0.00 & -0.05 & 0.00 \\
replacement & Normal & -0.03 & 0.00 & 0.00 & -0.01 & 0.00 & -0.05 & 0.00 \\
costs (€/sqm/m) & Min & -0.02 & 0.00 & 0.00 & -0.01 & 0.00 & -0.05 & 0.00 \\
Yield (\%-unit) & Max & $-0.13 \%$ & $-0.28 \%$ & $-0.18 \%$ & $-0.21 \%$ & $-0.13 \%$ & $-0.75 \%$ & $0.00 \%$ \\
& Normal & $-0.13 \%$ & $-0.28 \%$ & $-0.30 \%$ & $-0.25 \%$ & $-0.13 \%$ & $-0.75 \%$ & $0.00 \%$ \\
& Min & $-0.12 \%$ & $-0.28 \%$ & $-0.08 \%$ & $-0.17 \%$ & $-0.10 \%$ & $-0.75 \%$ & $0.00 \%$ \\
Property value & Max & 718,864 & $1,521,985$ & $1,069,806$ & $1,151,638$ & 961,278 & 273,333 \\
$(€)$ & Normal & 689,445 & $1,276,170$ & 987,143 & $1,021,104$ & 826,605 & 189,808 & $2,754,902$ \\
& Min & 587,572 & $1,288,779$ & 112,530 & 672,384 & 637,605 & $-967,891$ & $2,954,587$ \\
\hline & & & & & & & \\
& & & & & &
\end{tabular}

Table 4. Summary of the results

\begin{tabular}{|c|c|c|c|c|c|c|c|c|}
\hline Valuer & Rent & $\begin{array}{l}\text { Vacancy } \\
\text { rate }\end{array}$ & $\begin{array}{l}\text { Maintenance } \\
\text { costs }\end{array}$ & $\begin{array}{l}\text { Repair and } \\
\text { repl. costs }\end{array}$ & Yield & $\begin{array}{l}\text { Property } \\
\text { value }\end{array}$ & $\begin{array}{l}\text { Net operating } \\
\text { income }\end{array}$ & Exit value \\
\hline V1 & & & + & & + & + & + & + \\
\hline $\mathrm{V} 2$ & + & + & + & + & + & + & + & + \\
\hline I1 & & + & + & & + & + & + & + \\
\hline $\mathrm{I} 2$ & + & & & & + & + & + & + \\
\hline I3 & & + & + & & & + & + & + \\
\hline D1 & + & + & + & & + & + & + & + \\
\hline D2 & + & & & & + & + & + & + \\
\hline D3 & + & $+1-$ & & & + & $+1-$ & $+1-$ & $+1-$ \\
\hline
\end{tabular}

Figure 3 visualises information of Table 3 as percentage changes of the DCF parameters. Even though the average percentage changes in Figure 3 suggest that all of the parameters (with the exception of vacancy rate for Developers in the normal and min scenario) have a positive impact on the property value, the changes should be studied with caution because the individual responses do not follow systematically similar paths.

Comparing the findings of the literature review (see Table 1) to the percentage changes in Figure 3 , it can be noticed that the responses are in line with the theoretical and regression literature, i.e., it seems that in practice certified buildings are considered to be more valuable than non-certified buildings. Finally, in Table 4 is presented a simplified (i.e., in the table all of the three scenarios are presented in each row for illustration purposes, e.g., D3 decreased vacancy rate in max scenarios, but increased it in normal and min scenarios) sum- mary of what parameters are weighted by different participants. Additionally, a plus/minus sign means that the parameter has a positive/negative effect on the property value, respectively.

In the last section it was hypothesized that the participants will increase rent and decrease vacancy rate, maintenance costs, operating expenses (i.e., maintenance costs and repair and replacement costs), and yield that would eventually result in higher property values. Looking at Table 4, it can be noticed that property values were increased in every case (except in one out of 24 scenarios). This indicates that certified properties indeed have higher property values than non-certified properties. However, looking at different participants' adjustments of the DCF input parameters, it is hard to pinpoint exact parameters for the increased property value with the exception of yield that was improved by seven out of eight participants. This could be interpreted that most of the participants 


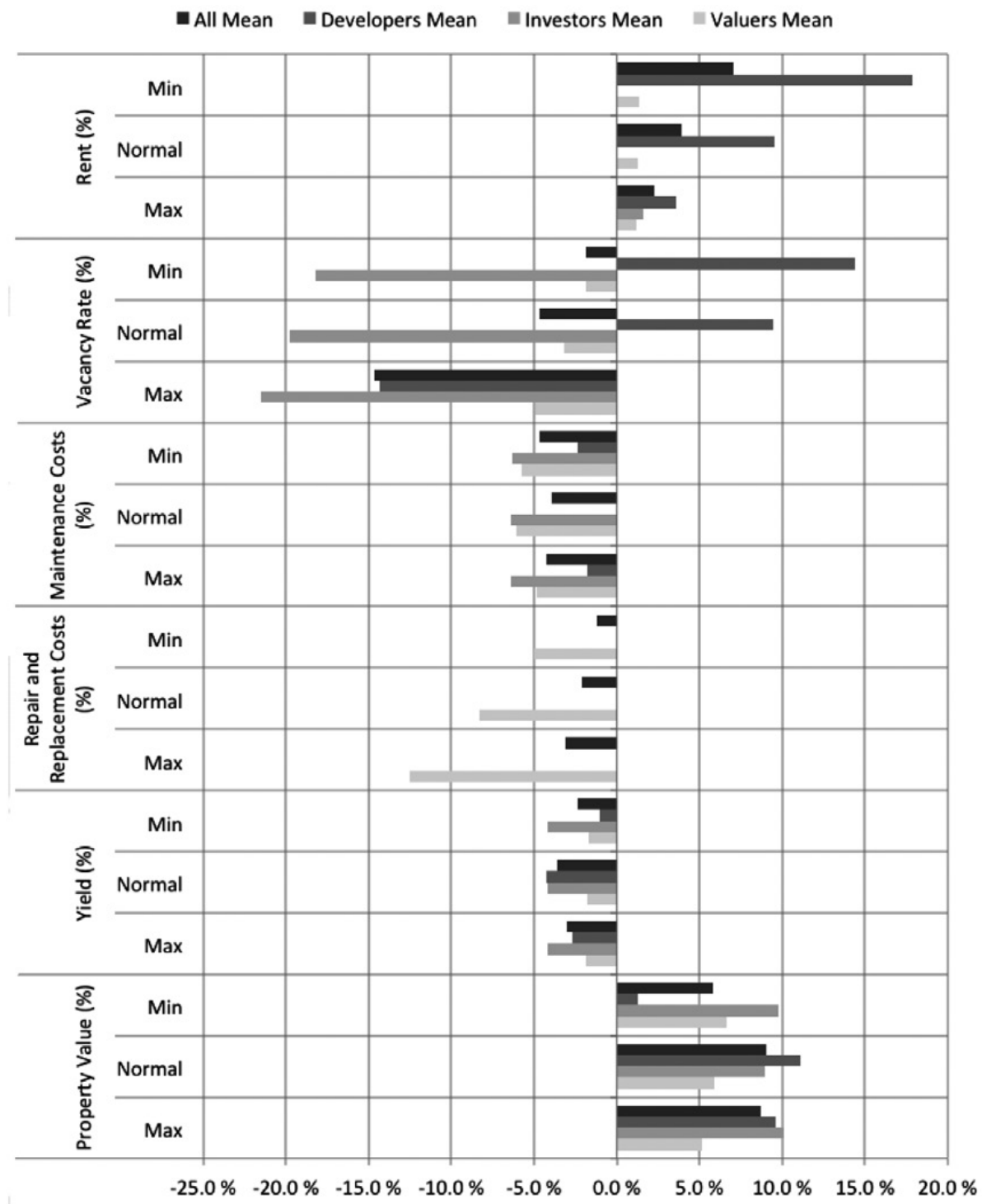

Fig. 3. Percentage changes in the DCF parameters

considers certified properties less risky than noncertified properties. Similarly, seven out of eight participants responded that the certificate does not have an effect in the parameter of Repair and Replacement Costs.

Table 4 can also be used for analysing the value influencing mechanism of the green certificate by examining each row as a single case study. This is done for understanding whether different participants have similar patterns in their responses, especially since every participant valued certified properties higher than non-certified properties. Two interesting observations were noticed. First, the participants (V1, I1, and I3) who did not increase rent, decreased maintenance costs. Second, the participants (I2, D2, and D3) who did not decrease maintenance costs, increased rents. Therefore, in addition to improved yield, all of the par- ticipants want to increase the net rental income (i.e., rent minus maintenance costs) for certified properties.

\section{CONCLUSIONS}

This research was set to shed light on the value influencing mechanism of green certificates in the discounted cash flow (DCF) valuation. A traditional DCF model for property valuation was constructed in spreadsheet programme and sent to different stakeholders (i.e., property valuers, investors, and developers) for valuing an office property in metropolitan Finland. The participants were asked to valuate the office property first without a certificate and then with a premium (LEED Platinum) certificate. Table 4 summarised the responses that were received from eight industry professionals 
(i.e., two valuers $(\mathrm{V})$, three investors $(\mathrm{I})$, and three developers (D)).

Based on the earlier research, it was hypothesized that the participants will increase rent and decrease vacancy rate, maintenance costs, operating expenses (i.e., maintenance costs and repair and replacement costs), and yield that would eventually result in higher property values. It was found that property values were increased in every case except one out of 24 scenarios. This indicated that certified properties indeed have higher property values than non-certified properties. However, it was hard to pinpoint exact parameters for the increased property value with the exception of yield that was adjusted downward by seven out of eight participants. This could be interpreted that most of the participants consider certified properties less risky than non-certified properties. Similarly, seven out of eight participants responded that the certificate does not have an effect in the parameter of Repair and Replacement Costs.

The value influencing mechanism of the green certificate was also examined by analysing each of the responses as individual cases. Two interesting observations were noticed. First, the participants (V1, I1, and I3) who did not increase rent, decreased maintenance costs. Second, the participants (I2, D2, and D3) who did not decrease maintenance costs, increased rents. Therefore, in addition to improved yield, all of the participants wanted to increase the net rental income (i.e., rent minus maintenance costs) for certified properties.

The main results of higher property values were expected even though it was surprising that the results were so consistent with each other: all of the participants valued certified properties higher. Additionally, based on the interviews with industry professionals, it was expected that different participants would weight different DCF input parameters differently. However, it was unexpected that yield was decreased in almost all of the responses. This was unexpected because yield often has the highest impact on property value, i.e., adjusting it would not be done lightly. On the other hand, earlier research indicates that certified buildings are less risky, and since yield measures risk, adjusting it is an easy way for incorporating the impact of a certificate in to the property valuation. In addition, since yield is the most subjective of the parameters, it might be the logical parameter for including the green certificate.

Finally, the results seem to suggest (based on analytical not a statistical generalization) that a green certificate increases on average the property value with $9.0 \%$ in the DCF valuation model. The finding is in line with the earlier theoretical studies presented in the literature review. All of respondents adjusted the DCF parameters to have a positive effect in the property value. The standard deviation of the positive effect was high, so there was not a clear consensus of the size of the positive impact between the respondents. It is notice worthy that the above deduction is based on the highest available LEED certificate, and thus cannot be generalized to all green certificates. Additionally, the scope of the research was Finnish office property market. The findings are based on a rather small sample size, partly because of the small number of property valuers, investors, and developers in the Finnish real estate and construction sector, and partly because a strong hypothesis could be constructed based on earlier literature and the study was sort of "critical case" design. Finally, the DCF is known for its weaknesses in producing reliable results, if the input parameters are not well founded.

Ideas for further research are 1) to expand the exercise to include more markets, countries and certificates, 2) do a time series study on a portfolio of green buildings on how DCF parameters increase/decrease compared to normal buildings, 3 ) if in the future there is enough statistical data to compare the parameters between actual sales transactions between certified / non-certified buildings, and 4) to study whether the DCF method is the best method for analysing the value of a green certificate.

\section{REFERENCES}

Chegut, A.; Eichholtz, P.; Kok, N. 2014. Supply, demand and the value of green buildings, Urban Studies 51(1): 22-43. http://dx.doi.org/10.1177/0042098013484526

Colliers. 2007. Canadian office tenant survey results: tenants reveal their desires of tomorrow, Colliers International,Toronto.

Cushman \& Wakefield. 2009. Landlord \& tenant survey. Cushman \& Wakefield, London.

Eichholtz, P.; Kok, N.; Quigley, J. 2010. Doing well by doing good? Green office buildings, American Economic Review 100(5): 2492-2509. http://dx.doi. org/10.1257/aer.100.5.2492

Eisenhardt, K.; Graebner, M. 2007. Theory building from cases: opportunities and challenges, Academy of Management Journal 50(1): 25-32. http://dx.doi. org/10.5465/AMJ.2007.24160888

Falkenbach, H.; Lindholm, A.; Schleich, H. 2010. Environmental sustainability: drivers for the real estate investor, Journal of Real Estate Literature 18(2): 201-223. 
French, N.; Gabrielli, L. 2004. The uncertainty of valuation, Journal of Property Investment \& Finance 22(6): 484-500. http://dx.doi. org/10.1108/14635780410569470

Fuerst, F.; McAllister, P. 2008. Green noise or green value? Measuring the effects of environmental certification on office values, Real Estate Economics 39(1): 45-69. http://dx.doi.org/10.1111/j.15406229.2010.00286.x

Fuerst, F.; McAllister, P. 2009a. New evidence on the green building rent and price premium, Working $P a-$ pers in Real Estate \& Planning, 07/09, University of Reading, Reading. 29 p.

Fuerst, F.; McAllister, P. 2009b. An investigation of the effect of eco-labeling on office occupancy rates, Journal of Sustainable Real Estate 1(1): 49-64.

Golubchikov, O. 2009. Green homes - towards energyefficient housing in the United Nations Economic Commission for Europe Region, United Nations, New York and Geneva.

GRESB. 2012. Global real estate sustainability benchmark [online]. Available at: http://www.gresb.com [assessed 30 November 2012]

Jones Lang LaSalle. 2008. Global trends in sustainable real estate: an occupier's perspective, JLL February.

KTI. 2013. KTI property information - definitions [online]. Available at: http://www.kti.fi [assessed 26 February 2013]

Lusht, K. M. 1997. Real estate valuation: principles \& applications, Times Mirror Higher Education Group, Chicago.

Kats, G. 2003. Green building costs and financial benefits, Massachusetts Technology Collaborative.

Matthiessen, L. F.; Morris, P. 2004. Costing green: a comprehensive cost database and budgeting methodology, Davis Langdon.

Matthiessen, L. F.; Morris, P. 2007. Cost of green revisited: re-examining the feasibility and cost impact of sustainable design in the light of increased market adoption, Davis Langdon.
McGareth, K. M. 2012. The effects of eco-certification on office properties: a cap rates-based analysis, Applied Research Working Paper Series, Coventry University Business School.

Miller, N.; Spivey, J.; Florance, A. 2008. Does green pay off?, Journal of Real Estate Portfolio Management 14(4): 385-399.

Pivo, G.; Fisher, J. 2009. Investment returns from responsible property investments: energy efficient, transit-oriented and urban regeneration office properties in the U.S. from 1998-2007, Working paper of Responsible Property Investing Center Boston College and University of Arizona, WP 08-2.

Reichardt, A.; Fuerst, F.; Rottke, N. B.; Zietz, J. 2012. Sustainable building certification and the rent premium: a panel data approach, Journal of Real Estate Research 34(1): 99-126.

Sayce, S.; Ellison, L.; Parnell, P. 2007. Understanding investment drivers for U.K. sustainable property, Building Research \& Information 35(6): 629-643. http://dx.doi.org/10.1080/09613210701559515

Shiers, D. E. 1999. "Green” developments: environmentally responsible buildings in the U.K. commercial property sector, Property Management 18(5): 352365. http://dx.doi.org/10.1108/02637470010360650

Turner, C.; Frankel, M. 2008. Energy performance of LEED ${ }^{\circledR}$ for new construction buildings, NBI New Buildings Institute, Vancouver, March.

UNPRI. 2012. Principles for responsible investment [online]. Available at: http://www.unpri.org [assessed 30 November 2012]

USGBC. 2012. U.S. Green Building Council [online]. Available at: http://www.usgbc.org [assessed 5 December 2012]

Wiley, J.; Benefield, J.; Johnson, K. 2010. Green design and the market for commercial office space, Journal of Real Estate Finance and Economics 41(2): 228243. http://dx.doi.org/10.1007/s11146-008-9142-2 


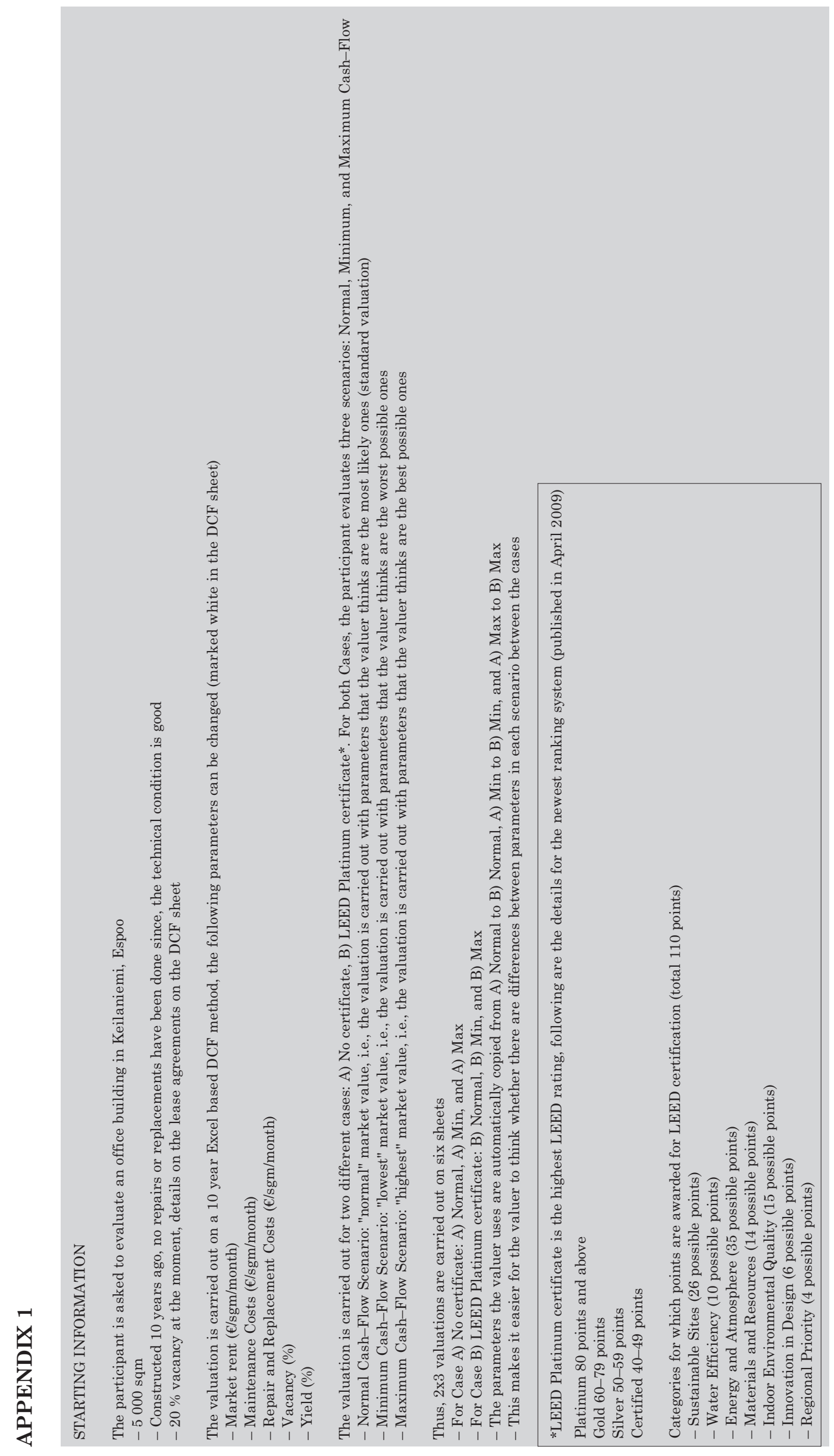




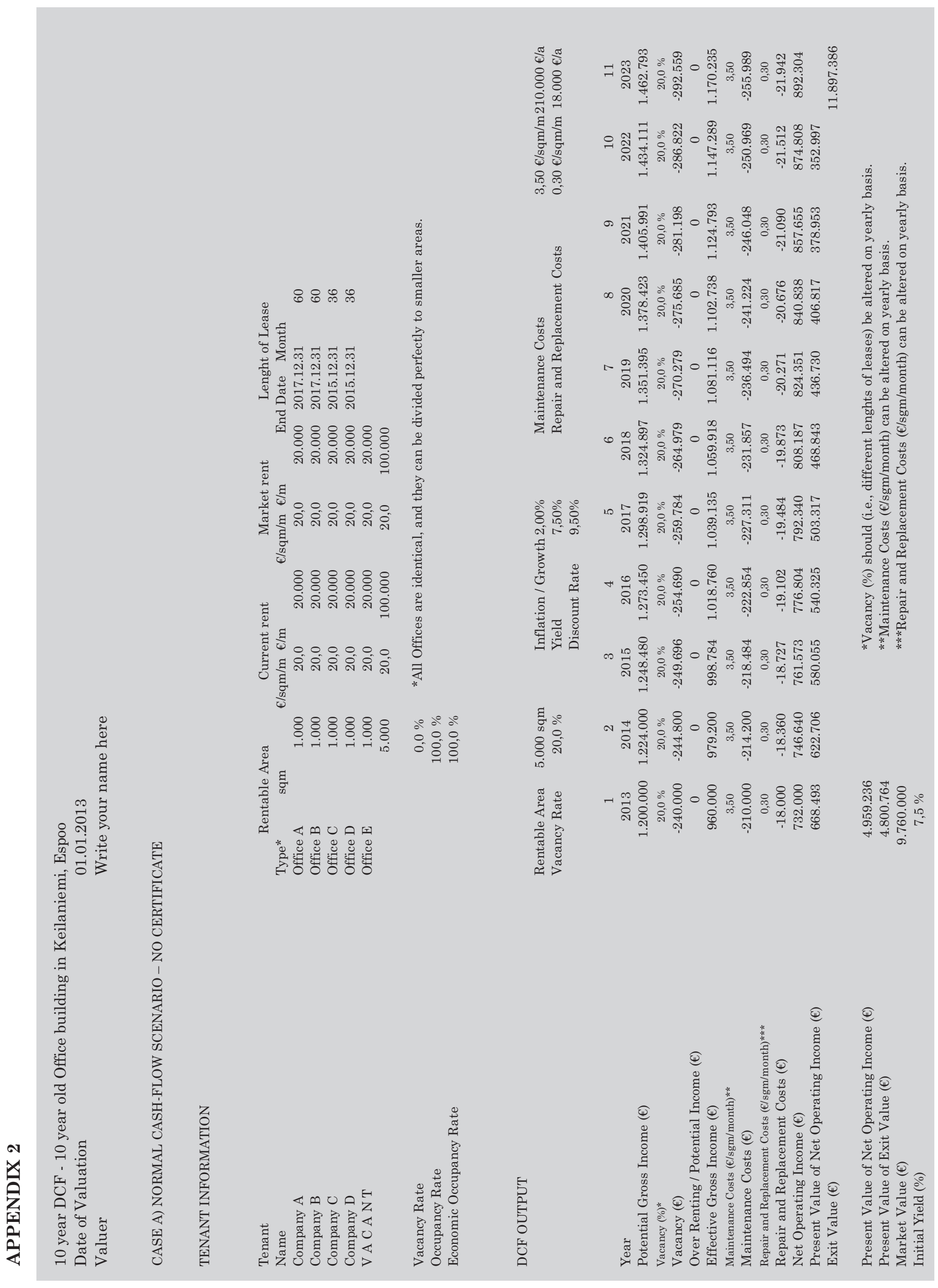

